\title{
Effect of Different Concentration of Orange Juice on Quality Characteristics of Soya Milk Blended Beverage
}

\author{
Kale RV ${ }^{1 *}$, Pandhare $\mathrm{GR}^{2}$, Satwase $\mathrm{AN}^{1}$ and Goswami $\mathrm{D}^{2}$ \\ ${ }^{1}$ Department of Food Science and Technology, MGM College of Food Technology, Aurangabad 431003 (MS), India \\ ${ }^{2}$ Department of Chemical Technology, Dr. Babasaheb Ambedkar Marathwada University, Aurangabad (MS), India
}

\begin{abstract}
In present investigation the efforts have been made to prepare orange juice fortified soya milk beverage. The blends were prepared by using different proportions of orange juice and soya milk as 10:90, 20:80, and 30:70 up to $90: 10$. The different blends were homogenized and pasteurized at $8000 \mathrm{rpm}$ for $2 \mathrm{~min}$ and $85^{\circ} \mathrm{C}$ for 10 minutes respectively. The prepared beverage was analyzed for its different physicochemical as well as organoleptic properties. Organoleptic evaluation of beverages showed that orange soy RTS beverage prepared from $80 \%$ orange juice blended in soy milk founded to be best according to physico- chemical properties followed by the $70 \%$ orange juice blend, 60 , and $50 \%$ orange juice blended in soy milk found to have good taste and overall acceptability. This could be beneficial to communities where cow's milk is unacceptable, unavailable or unaffordable or due to lactose intolerance.
\end{abstract}

Keywords: Soya milk; Orange juice; Fruit blended beverage

Abbreviations: RTS - Ready to serve; RPM - Revolutions per minute

\section{Introduction}

Soybean (Glycine max L.) is the one of the most important legume seed because of its high nutritive value. These are "the miracle golden beans of the twentieth century" has revolutionized the agricultural as well as general economy of many countries. Soybean has been cultivated in India from sufficiently long time, mostly in hilly areas, but very recently it has occupied very important position at the national level. A programme for the development of the soybean has been taken up in the many agricultural universities and research stations [1].

Now-a-days the protein calories malnutrition is wide spread in the country. This is because majority of Indian population is vegetarian and solely depends on pulses for their protein need. Protein malnutrition is more severe in the children and nearly $80 \%$ of children are suffering from malnutrition disorder. In view of bridging up the gap between requirement and availability of protein, soybean is most important grain legume and its importance is increasing day by day due to its high nutritive value.

The protein of soybean is of biological value and resembles protein in fish, poultry, meat and eggs. Soybean has been major substitute as a cheaper protein and can be introduced in the diet of common people. The vitamin and mineral constituent of soybean might also prove to be decisive. It is very rich in mineral substances such as $\mathrm{P}_{2} \mathrm{O}_{5}, \mathrm{Fe}$ and vitamins $\mathrm{A}, \mathrm{D}$, and $\mathrm{B}$. Soaked seeds and sprout contain vitamin $\mathrm{C}$ which is found in fresh fruits and green vegetables [2].

Soybean is used for preparation of bread, biscuits, cakes and chocolates. "It is the milk harvested from the field without cow". The soybean milk i.e. prepared from soybean flour and can be compared with cow milk (U.S.A. Agril Dept Bulletin, 1939).

Many dairy analogues of acceptable quality have been developed from soybeans. These products are becoming increasingly popular in western countries because of the desire of the people to reduce their intake of cholesterol and in higher cost of milk and milk products.
The major components of the soybean seeds are oil and protein making up about $60 \%$ of the beans and about one -third carbohydrates that is polysaccharides such as stachyose (3.8\%), raffinose (1.1\%), phospholipids, sterols, ash and other minor constituents are also present. Soybean is rich in protein (about $40 \%$ ) which is substantially higher than any other grain legume [3].

The most important factor which hampers its utilization is its beany flavor which is due to ethyl-vinyl ketone, other lipids and presence of trypsin inhibitor which severally reduce the digestibility of soy protein. These are some negative parameters consider for its utilization. This can be solving by processing of soybeans in to products.

"Beany" flavor is indeed the principal inconvenience of traditional soymilk. This objectionable flavor comes from some ketones and aldehydes, particularly hexanals and heptanals, produced through lipoxidase-catalyzed oxidation of soybean oil. These compounds are not present in sound, dry soybeans but are produced as soon as the beans are wetted and ground. Several approaches have been used to overcome the problem of off flavors in soymilk.

Soy milk, a stable emulsion of oil, water and protein, is simply an aqueous extract of whole soybeans. The liquid is produced by soaking dry soybeans, and grinding them with water. Soy milk contains about the same proportion of protein as cow's milk-around 3.5\%; also $2 \%$ fat, $2.9 \%$ carbohydrate and $0.5 \%$ ash. Soy milk can be made at home with traditional kitchen tools or with a soy milk machine.

*Corresponding author: Kale RV, Department of Food Science and Technology, MGM College of Food Technology, Aurangabad 431003 (MS), India, Tel: +919503134531(R), +91240-6601403(O); E-mail: ravindra.foodtech@gmail.com

Received November 24, 2011; Accepted December 14, 2011; Published December 16, 2011

Citation: Kale RV, Pandhare GR, Satwase AN, Goswami D (2012) Effect of Different Concentration of Orange Juice on Quality Characteristics of Soya Milk Blended Beverage. J Food Process Technol 3:140. doi:10.4172/21577110.1000140

Copyright: @ 2012 Kale RV, et al. This is an open-access article distributed under the terms of the Creative Commons Attribution License, which permits unrestricted use, distribution, and reproduction in any medium, provided the original author and source are credited. 
Citation: Kale RV, Pandhare GR, Satwase AN, Goswami D (2012) Effect of Different Concentration of Orange Juice on Quality Characteristics of Soya Milk Blended Beverage. J Food Process Technol 3:140. doi:10.4172/2157-7110.1000140

Page 2 of 5

During the last years, soy beverages consumption has gradually increased due to their significant concentration of health-promoting compounds, such as isoflavones. Epidemiological and clinical studies suggest that consumption of a diet rich in isoflavones is associated with low risk of the so-called Western diseases [4], such as coronary heart disease [5], osteoporosis, menopausal symptoms, hormone-dependent cancers [6], obesity, and diabetes.

At the present time, several fruit juice blended soy beverages are available in the market [7]. Therefore, in present investigation efforts have been focused to develop soy beverages fortified orange juice, which may lead to improve sensorial characteristics as well as nutritional properties. Usually, thermal treatments are applied to prolong the shelf-life of this type of beverages by the inactivation of microorganisms and enzymes.

\section{Materials and Methods}

\section{Raw materials}

Raw materials such as soybean and orange for present investigation were procured from local market, Aurangabad.

Chemicals such as Sodium bicarbonate, sodium carbonate, Sodium alginate, amyl alcohol, sulphuric acid, citric acid, and pectin all these chemicals were of Food grade and made available from University Department of chemical Technology, Dr.BAMU, Aurangabad.

\section{Treatment for removal of beany flavor of soybeans}

Soy milk has a characteristic beany or nutty flavor, which was mainly due to lipoperoxidation of polyunsaturated fatty acids (PUFA) mediated by lipoxygenases isozyme activity. These off- flavors could not be completely eliminated but minimized to a greater extent by heat treatment, alkali treatment or cleanliness. The use of a hot water and sodium bicarbonate helps to remove its beany flavor [8].

\section{Manufacturing process for production of Soy milk} $1[9]$.

Soya milk was produced as per ILLINOIS process given in figure

Preparation of orange juice: Good quality Oranges were collected from local market Aurangabad. As shown in figure 2 they were peeled to remove outer skin. Bitterness in the juice can be reduced considerably by extracting the juice from the segments dipped into $2 \%$ boiling alkali for 30-60 seconds to remove the outer covering of the segments and fibrous material, (Preservation of Fruits and Vegetables, Siddhappa).

Then juice extracted through Juicer (Model No.MS-3427) and filtered through muslin cloth. Chien and Snyder [10] reported that soymilk tasted less astringent by the addition of skimmed cow's milk, $\mathrm{CaSO}_{4}$, or citric acid. Then stabilizers pectin or sodium alginates were used at the rate of $0.4 \%$ and $0.6 \% \mathrm{w} / \mathrm{w}$ respectively [11]. Then juice was pasteurized at $90^{\circ} \mathrm{C}$ for $1 \mathrm{~min}$ filled in sterile glass bottle crown cork and air cooled [12].

Production of orange soy RTS beverage: Orange juice was used to mix with soy milk. Orange juice was blended in different proportions i.e. having orange juice: Soy milk in proportions from 10:90, 20:80, and 30:70 up to 90:10 and given numbers as blend 1, blend 2, blend 3, up to blend 9. The different blends are homogenized at $8000 \mathrm{rpm}$ for $2 \mathrm{~min}$ in homogenizer (127A Remi motors, Mumbai).The obtained beverage was pasteurized at $85^{\circ} \mathrm{C}$ for $10 \mathrm{~min}$ and hot filled into sterile bottles keeping about $6 \%$ head space [13].
Beverage samples were stored in refrigerator at $4^{\circ} \mathrm{C}$. The beverage samples then on second day were withdrawn and analyzed for $\mathrm{pH}$ T.S.S., \%Acidity, Viscosity, \% fat, Protein and Sensory characteristics.

\section{Physicochemical analysis}

Determination of moisture content: Moisture content was determined for $5 \mathrm{~g}$ of sample taken in petri plates. The samples were oven dried at $\pm 105^{\circ} \mathrm{C}$ for $12 \mathrm{~h}$ in pre-weighed Petri dishes with removed lids [14]. After drying petri dishes were covered with lid and cooled in desiccators containing silica gel for $1 \mathrm{~h}$ before weighing. Moisture content of whole sample is calculated by,

$$
\begin{aligned}
& \text { Drymatter }=\frac{\left(w_{2}-w_{3}\right)}{\left(w_{3}-w_{1}\right)} \times 100 \\
& \text { Moisture Content }(\% \text { d.b })=\frac{\left(w_{2}-w_{3}\right)}{\left(w_{3}-w_{1}\right)} \times 100 \\
& \text { Moisture Content }(\% \text { w.b })=\frac{\left(w_{2}-w_{3}\right)}{\left(w_{2}-w_{1}\right)} \times 100
\end{aligned}
$$

Where, $\mathrm{W}_{1}, \mathrm{~W}_{2}$ and $\mathrm{W}_{3}$ are weights of empty Petridish, Petridish + sample before drying and Petridish + sample after drying.

Determination of protein content: Protein content was

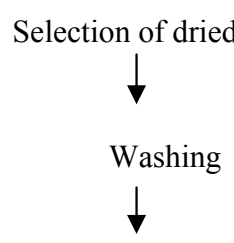

Soaking in $5 \% \mathrm{NaHCO}_{3}$ and $\mathrm{NaCO}_{3}$ for $16-18$ hour

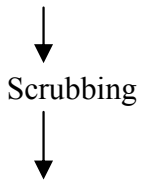

Hot treatment $\left(100^{\circ} \mathrm{C}\right.$, for $40-45$ minutes $)$
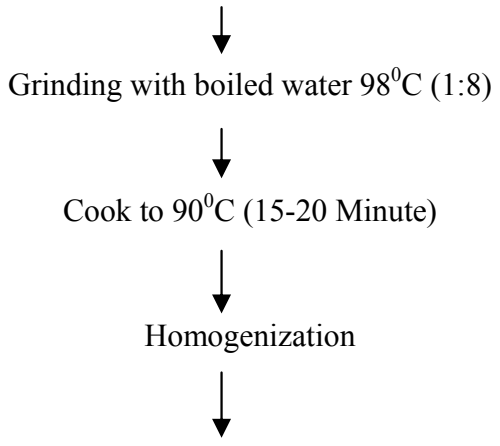

Clarification of insoluble and soluble portion

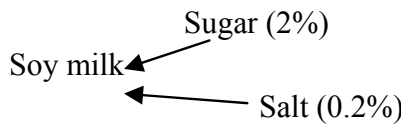

Figure 1: Process flow chart for production of soy milk. 
Citation: Kale RV, Pandhare GR, Satwase AN, Goswami D (2012) Effect of Different Concentration of Orange Juice on Quality Characteristics of Soya Milk Blended Beverage. J Food Process Technol 3:140. doi:10.4172/2157-7110.1000140

determined by Microkjheldhal method $(\mathrm{N} \times 6.25)$ as per procedure of A.O.A.C [14].

$$
\% \mathrm{~N}=\frac{(\text { Sample-blank }) \times \text { Nof HCL } \times 0.014 \times 6.25 \times 100}{\text { Aliquotetaken } \times \text { Wtofsample }(\text { gm)taken }}
$$

Determination of ash content: Ash content was determined by the method of A.O.A.C. [14] Take $5 \mathrm{~g}$ of sample in silica crucible was ignited on low flames till smokeless and incinerated in muffle furnace at $550^{\circ} \mathrm{C}$ for 5 hours. It was then cooled in desiccators and weighed.

$$
\% \text { Ash }=\frac{\text { Wt of ash }}{\text { Wt of sample }} \times 100
$$

Waste index: It was calculated by following formulae.

Waste index $(\%)=\frac{\text { Weight of fruit }(\mathrm{g})-\text { Weight of juice }(\mathrm{g})}{\text { Weight of fruit }(\mathrm{g})} \times 100$

Percentage yield of juice: The Percentage yield of juice was calculated on the basis of weights of juice obtained after peeling.

$$
\% \text { yield }=\frac{\text { Weight of juice }(\mathrm{g})}{\text { Weight of fruit }(\mathrm{g})} \times 100
$$

\section{Rheological properties}

Viscosity of the prepared beverage and soymilk was measured using Brookfield Viscometer (DV-E, Brookfield Engineering lab INC, USA). Beverage was transferred into beaker and the bob was immersed so that beverage just covered the edge of bob without overflowing onto its top. Temperature of the sample was maintained constant $\left(25^{\circ} \mathrm{C}\right)$ which was achieved by keeping it in water bath. Viscosity and consistency are important attributes for beverage. Gums were added to beverage to improve their quality by acting as thickening and emulsifying agents.

\section{Organoleptic evaluation}

The beverage samples were evaluated in a sensory laboratory under white light for attributes of Appearance, color, taste, mouth feel, flavor and overall acceptability by a preference method [15] on a 9-point hedonic scale.

\section{Result and Discussion}

\section{Proximate analysis of fresh juice}

The result obtained on physico- chemical properties of fresh juice for making Orange soy RTS beverage were presented in Table 1.

\section{Physicochemical characteristics of soy milk}

The result obtained on preparation of Soy milk was represented in Table 2.

The mass fraction of Moisture Content, Carbohydrates + Ash, Protein and Crude Fat were found to be within the range repaired by Wang et al. [16] (Figure 3)

\section{Physicochemical characteristic of finished orange juice}

The results obtained on physico- chemical properties of finished orange juice were presented in Table 3.

\section{Physicochemical characteristic of orange soy RTS beverage}

Ten blends of Orange soy RTS beverage were prepared with different proportions of orange juice and soy milk. Two control samples

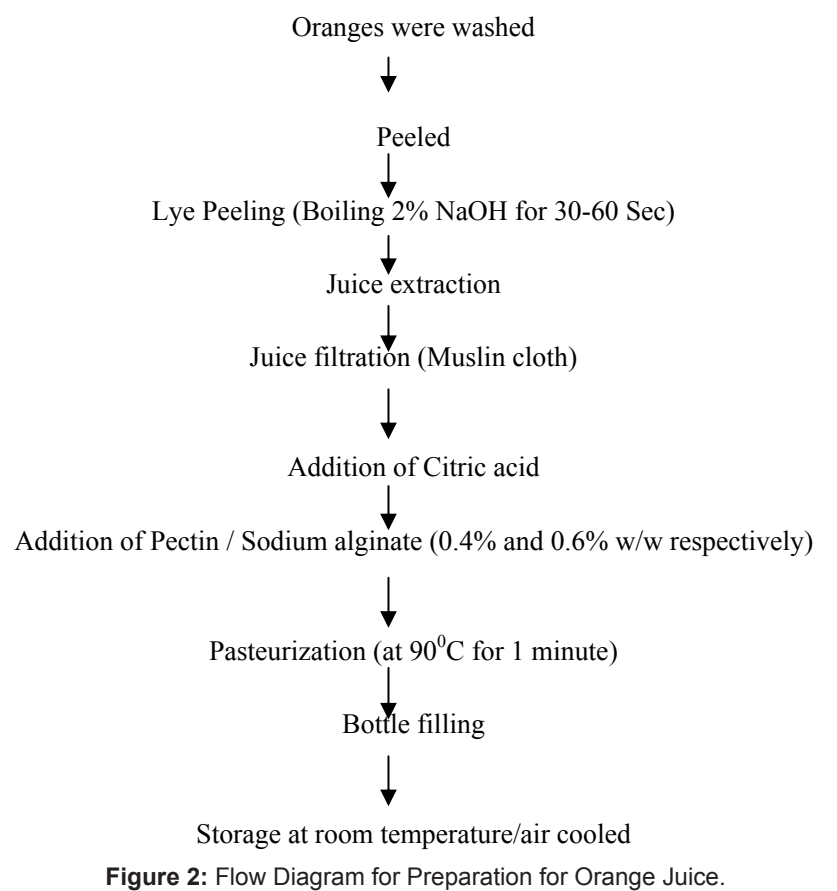

\begin{tabular}{|c|c|c|}
\hline Sr. No. & Parameter & Values \\
\hline 1. & \% Acidity (citric acid) & $0.75 \pm 0.02$ \\
\hline 2. & T.S.S & $10.6 \pm 0.15^{\circ} \mathrm{Brix}$ \\
\hline 3. & Initial weight & $1250 \mathrm{~g}$ \\
\hline 4. & Weight of juice & $1000 \mathrm{~g}$ \\
\hline 5. & \% waste index & $19.996 \pm 0.588$ \\
\hline 6. & $\%$ yield of orange juice & $80.286 \pm 0.245$ \\
\hline
\end{tabular}

*Each value is mean observation in triplicate \pm SD (standard deviation)

Table 1: Physico- chemical properties of fresh juice.

\begin{tabular}{|c|c|c|}
\hline Sr. No. & Parameter & Values \\
\hline 1. & Moisture Content & $85.7 \pm 0.66 \%$ \\
\hline 2. & Carbohydrates +Ash & $10.29 \pm 0.45 \%$ \\
\hline 3. & Protein & $2.3 \pm 0.15 \%$ \\
\hline 4. & Crude Fat & $1.5 \pm 0.1 \%$ \\
\hline 5. & T.S.S. & $3 \pm 0.5^{\circ} \mathrm{Brix}$ \\
\hline 6. & Viscosity & $10.06 \pm 0.53 \mathrm{cP}$ \\
\hline 7. & $\%$ Acidity & $0.128 \pm 0.1$ \\
\hline
\end{tabular}

*Each value is mean observation in triplicate \pm SD (standard deviation)

Table 2: Physicochemical Characteristics of Soy milk.

(soy milk and orange juice) were taken for analyzed comparative physicochemical changes in Orange soy RTS beverage. Result obtained with respect to physicochemical characteristics of prepared Orange soy RTS beverage were represented in Table 4 below.

Result shows that with the increase in juice concentration percent acidity, T.S.S. and viscosity increased. While $\mathrm{pH}$ and fat content reduced subsequently.

\section{Organoleptic evaluation of orange soy RTS beverage}

Figure 4 showed that the panelist preferred fruit blended soy milk i.e. orange over plain soy milk. $10 \%$ of orange juice blend in soy milk gave lowest score i.e. 4 for Appearance while $80 \%$ of orange juice blend 
Citation: Kale RV, Pandhare GR, Satwase AN, Goswami D (2012) Effect of Different Concentration of Orange Juice on Quality Characteristics of Soya Milk Blended Beverage. J Food Process Technol 3:140. doi:10.4172/2157-7110.1000140

Page 4 of 5

gave highest score for appearance. Lowest score obtained for color was to $10 \%$ orange juice blend and highest score was given to $80 \%$ blend. Panelists liked taste of $80 \%$ orange juice blend very much as compared to other blends. Panelist liked taste of orange soy RTS beverage containing 50,60, and 70\% of orange juice moderately. Panelist liked mouth feel of Orange soy RTS beverage containing $80 \%$ orange juice blend extremely giving highest score (8), 70, 60, 50\% orange juice blend which liked by the panelist moderately. Lowest score for mouth feel was given to plain soy milk. Lowest score for flavor was given to plain soy milk which was founded to have slightly beany flavor. Panelist liked the flavor of Orange soy RTS beverage containing $80 \%$ orange juice blend. Flavor of $70,60,50 \%$ orange juice blend was liked moderately by panelist. Overall acceptability Orange soy RTS beverage containing $80 \%$ orange juice blend was given highest score by panelist (i.e.8), followed by $70,60,90,50 \%$ of orange juice blend. Overall acceptability was found to be lowest for orange soy RTS beverage containing $10 \%$ orange juice blend.

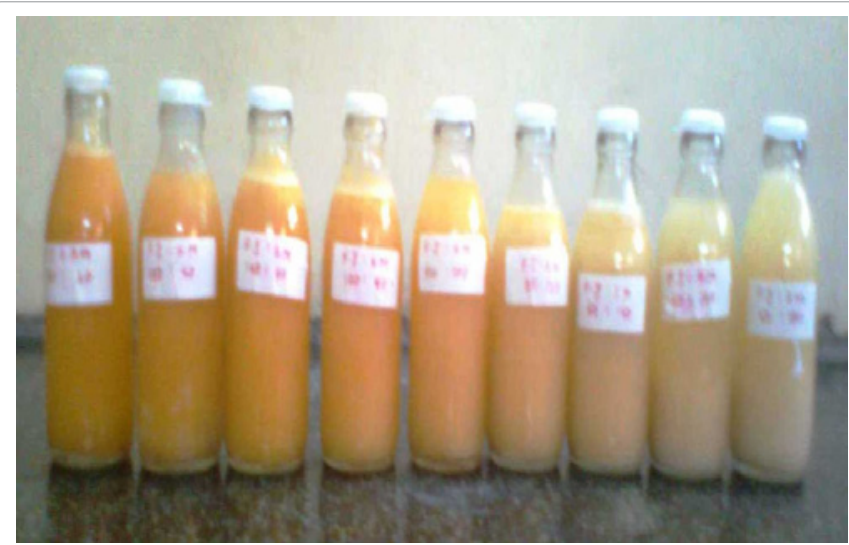

Figure 3: Orange soy RTS beverage.

\begin{tabular}{|c|c|}
\hline Parameter & Values \\
\hline T.S.S & $24.16 \pm 1.25^{\circ}$ Brix \\
\hline \% Acidity & $0.76667 \pm 0.07$ \\
\hline pH & $3.88 \pm 0.07$ \\
\hline Viscosity & $55.33 \pm 1.53 \mathrm{cP}$ at $25^{\circ} \mathrm{C}$ \\
\hline
\end{tabular}

*Each value is mean observation in triplicate \pm SD (standard deviation)

Table 3: Physicochemical Characteristics of orange juice.

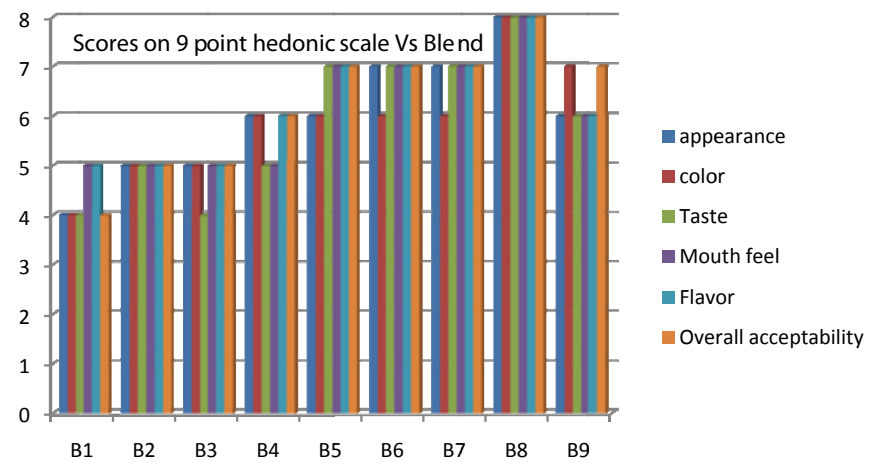

Where, $\mathrm{B} 1, \mathrm{~B} 2 \ldots=$ different proportions of orange juice from 10 to $90 \%$ blended in Soymilk.

Figure 4: Organoleptic evaluation of Orange soy RTS beverage.

\begin{tabular}{|c|c|c|c|c|c|}
\hline $\begin{array}{c}\text { Blend } \\
\text { No. }\end{array}$ & $\%$ Acidity & $\begin{array}{c}\text { T.S.S } \\
\left({ }^{\circ} \text { Bxix }\right)\end{array}$ & pH & $\begin{array}{c}\text { Viscosity } \\
\text { Cp }\end{array}$ & $\begin{array}{c}\text { Fat } \\
\%\end{array}$ \\
\hline $\mathbf{1}$ & $0.064 \pm 0.12$ & $5 \pm 0.5$ & $5.6 \pm 0.35$ & $6.5 \pm 0.25$ & $1.35 \pm 0.01$ \\
\hline $\mathbf{2}$ & $0.1344 \pm 0.056$ & $6.6 \pm 0.34$ & $4.8 \pm 0.38$ & $10.5 \pm 1.5$ & $1.2 \pm 0.02$ \\
\hline $\mathbf{3}$ & $0.192 \pm 0.035$ & $9.3 \pm 0.74$ & $4.4 \pm 0.62$ & $13 \pm 0.5$ & $1.05 \pm 0.01$ \\
\hline $\mathbf{4}$ & $0.2688 \pm 0.012$ & $11 \pm 0.5$ & $4.3 \pm 0.72$ & $16 \pm 1.32$ & $0.9 \pm 0.01$ \\
\hline $\mathbf{5}$ & $0.3456 \pm 0.012$ & $12.2 \pm 0.47$ & $4.1 \pm 0.16$ & $17.5 \pm 1.05$ & $0.75 \pm 0.02$ \\
\hline $\mathbf{6}$ & $0.4416 \pm 0.24$ & $14.2 \pm 0.34$ & $4.1 \pm 0.37$ & $27.5 \pm 0.64$ & $0.6 \pm 0.01$ \\
\hline $\mathbf{7}$ & $0.4864 \pm 0.046$ & $16.16 \pm 0.76$ & $4 \pm 0.05$ & $28.5 \pm 1.04$ & $0.45 \pm 0.01$ \\
\hline $\mathbf{8}$ & $0.5696 \pm 0.029$ & $17.3 \pm 0.54$ & $3.9 \pm 0.54$ & $32.5 \pm 1.25$ & $0.3 \pm 0.01$ \\
\hline $\mathbf{9}$ & $0.64 \pm 0.014$ & $20.2 \pm 0.37$ & $3.9 \pm 0.39$ & $38 \pm 1.47$ & $0.15 \pm 0.02$ \\
\hline
\end{tabular}

*Each value is mean observation in triplicate \pm SD (standard deviation)

Table 4: Effect of blending Orange juice on physicochemical characteristic of soy RTS beverage.

\section{Conclusion}

The present investigation on Studies on Development of orangesoy RTS beverage were undertaken to remove the beany flavor from soybean ,to formulate the product that is orange soy RTS beverage, to analyze the different proportions blends of Orange soymilk RTS beverage with respect to physico-chemical composition and analyze the Organoleptic characteristics of prepared orange soy RTS beverage. Organoleptic evaluation of beverages showed that orange soy RTS beverage prepared from $80 \%$ orange juice blended in soy milk founded to be best according to physico- chemical properties. Followed by the $70 \%$ orange juice blend, 60 , and $50 \%$ orange juice blended in soy milk found to have good taste and overall acceptability. Study reveals that fruits could be used in making the beany flavor thus promoting acceptability of soymilk. This could be beneficial to communities where cow's milk is unacceptable, unavailable or unaffordable or due to lactose intolerance.

\section{Recommendation}

Use of these beany flavor masking agents could enhance consumption of soybean in form of soymilk and thus needed to be promoted as one of the costeffective sustainable approaches in the promotion of wide soybean consumption in India.

\section{References}

1. Balsubramanian N (1972) Editorial Note. J of Nutrition 6: 2-6.

2. Kale FS (1940) Soybean its value in dietetics, cultivation and uses.

3. Endres JG (2001) Historical Aspects of soybean. Soy Protein Products Characteristics, Nutritional Aspects, and Utilization, AOCS, Champaign, IL, USA.

4. Adlercreutz H, Mazur W (1997) Phyto-estrogens and Western diseases. Ann Med 29: 95-120.

5. Anderson JW, Johnstone BM, Cook-Newell ME (1995) Meta-analysis of the effects of soy protein intake on serum lipids. N Engl J Med 333: 276-282.

6. Peeters PH, Keinan- Boker L, Van Der Schouw YT, Grobbee DE (2003) Phytoestrogens and breast cancer risk: Review of the epidemiological evidence. Breast Cancer Research and Treatment 77: 171-183.

7. Rostango MA, Palma M, Barroso CG (2007) Ultrasound-assisted extraction of isoflavones from soy beverages blended with fruit juices. Analytica Chimica Acta 597: 265-272.

8. Kumar V, Patra S, Anita R, Prakash TS (2002) Indian soybean varieties with low levels of lipoxygenases isozyme. J Food Sci Technol 39: 74-75. 
Citation: Kale RV, Pandhare GR, Satwase AN, Goswami D (2012) Effect of Different Concentration of Orange Juice on Quality Characteristics of Soya Milk Blended Beverage. J Food Process Technol 3:140. doi:10.4172/2157-7110.1000140

Page 5 of 5

9. Chen S (1989) Principles of Soymilk Production. Food Uses of Whole Oilseeds and Protein Seeds, American Oil Chemists Society, Champaign, IL, USA.

10. Chien JT, Snyder HE (1983) Detection and control of soymilk astringency. J Food Sci 48: 438-440.

11. Kumar P, Mishra HN (2004) Mango fortified set yoghurt: effect of stabilizer addition on physicochemical sensory and textural properties. Food Chem 87: 501-507.

12. Jain SK, Khuradiya DS (2004) Vitamin C enrichment of fruit juice based readyto-serve Beverage through blending of Indian Gooseberry (Emblica Officinalis Gaertn ) juice. Plant Foods Hum Nutr 59: 63-66.
13. Baghaei H, Shahidi F, Varidi MJ, Mahallati MN (2008) Orange-Cantaloupe seed beverage: Nutritive value, Effect of storage Time and Condition on Chemical Sensory and Microbial properties. World Applied Sci J 3: 753-758.

14. AOAC (1990) Official Methods of Analysis. Association of official Analytical chemists $\left(15^{\text {th }}\right.$ Edn), Washington DC.

15. Amerine A, Pangborn RM, Rossler EB (1965) Principles of sensory evaluation of food. Academic Press New York: 602.

16. Wang B, Xiong YL, Wang C (2001) Physicochemical and sensory characteristics of flavored soymilk during refrigeration storage. J Food Quality 24: 513-526. 